\title{
Transfer of auxinic herbicide resistance from Brassica kaber to Brassica juncea and Brassica rapa through embryo rescue
}

\author{
J. Mithila $\cdot$ J. Christopher Hall
}

Received: 6 September 2012 / Accepted: 18 March 2013 /Published online: 24 April 2013 / Editor: Charles Armstrong

(C) The Author(s) 2013. This article is published with open access at Springerlink.com

\begin{abstract}
Auxinic herbicides are widely used in agriculture to selectively control broadleaf weeds. Prolonged use of auxinic herbicides has resulted in the evolution of resistance to these herbicides in some biotypes of Brassica kaber (wild mustard), a common weed in agricultural crops. In this study, auxinic herbicide resistance from $B$. kaber was transferred to Brassica juncea and Brassica rapa, two commercially important Brassica crops, by traditional breeding coupled with in vitro embryo rescue. A high frequency of embryo regeneration and hybrid plant establishment was achieved. Transfer of auxinic herbicide resistance from B. kaber to the hybrids was assessed by whole-plant screening of hybrids with dicamba, a widely used auxinic herbicide. Furthermore, the hybrids were tested for fertility (both pollen and pistil) and their ability to produce backcross progeny. The auxinic herbicide-resistant trait was introgressed into B. juncea by backcross breeding. DNA ploidy of the hybrids as well as of the backcross progeny was estimated by flow cytometry. Creation of auxinic herbicide-resistant Brassica crops by nontransgenic approaches should facilitate effective weed control, encourage less tillage, provide herbicide rotation options, minimize occurrence of herbicide resistance, and increase acceptance of these crops.
\end{abstract}

\section{J. Mithila $(\bowtie)$}

Department of Agronomy, Kansas State University, Manhattan,

KS, USA

e-mail:mithila@k-state.edu

J. C. Hall

School of Environmental Sciences, University of Guelph, Guelph,

ON, Canada

J. C. Hall ( $₫)$

Department of Environmental Biology, University of Guelph,

Guelph, ON N1G 2W1, Canada

e-mail: jchall@uoguelph.ca
Keywords Auxinic herbicides · Embryo rescue - Dicamba · Introgression

\section{Introduction}

The family Brassicaceae is composed of several agronomically important crop species, including oilseed rape (Brassica napus), Indian mustard (Brassica juncea), cabbage (Brassica oleracea), and turnip mustard (Brassica rapa). Brassica crops are among the oldest, cultivated plants, and their importance dates back to $1500 \mathrm{BC}$. This family also includes an excellent reservoir of genes for many economically important traits and is receptive to gene transfer techniques. The wild species of Brassicaceae are sources of many agronomically important traits, such as resistance to pests and diseases and tolerance to abiotic stresses. Brassica kaber (syn. Sinapis arvensis), commonly known as wild mustard, is a dicot weed that infests both dicot and cereal crops, resulting in an estimated yield loss of 20 to $60 \%$ (Buchanan et al. 2009). To minimize crop yield loss by $B$. kaber competition, herbicides are commonly used. Specifically, auxinic herbicides, such as 2,4-dichlorophenoxyacetic acid (2,4-D) and dicamba, are widely used in cereal crops to selectively control broadleaf weeds including $B$. kaber. Due to prolonged use of auxinic herbicides in wheat and barley fields in western Canada, some biotypes of $B$. kaber evolved resistance to these herbicides. These $B$. kaber biotypes were highly resistant to dicamba and moderately resistant to 2,4D (Heap and Morrison 1992). The auxinic herbicideresistant (R) B. kaber biotype has been used as a model species to investigate the physiological, biochemical, and molecular basis of resistance to these herbicides (Penuik et al. 1993; Webb and Hall 1995; Hall et al. 1996; Zheng and Hall 2001; Mithila and Hall 2007; Mithila et al. 2012).

Gene transfer among members of Brassicaceae has been investigated (Prakash and Hinata 1980; Bing et al. 1995; Hu 
2002) and the transfer of agronomically important traits has occurred. Resistance to blackleg infection caused by Leptosphaeria maculans was transferred from B. kaber to $B$. napus (Snowdon et al. 2000). Similarly, powdery mildew resistance was transferred from $B$. oleracea to Brassica carinata (Tonguc and Griffiths 2004). Nonetheless, trait transfer among Brassica members is not always straightforward, due to variations in chromosome number as well as ploidy among species (Mizushima 1950, 1980). Therefore, in vitro techniques such as ovule/embryo rescue is commonly employed to successfully produce interspecific hybrids among Brassica members (Inomata 1988; Mathias 1991; Bing et al. 1995; Momotaz et al. 1998; Tonguc and Griffiths 2004).

Classical genetic studies demonstrated that $B$. kaber auxinic herbicide resistance is determined by a single dominant gene (Jasieniuk et al. 1995; Jugulam et al. 2005). The single gene inheritance facilitates the transfer of genes among related species. Because cultivated Brassica crops are sensitive to auxinic herbicides, we investigated the transfer of auxinic herbicide resistance from the weedy diploid $B$. kaber (2n:18) to two Brassica crop species, B. juncea, an allotetraploid (2n:36), and B. rapa, a diploid (2n:20), using conventional breeding combined with ovule/embryo rescue technique.

\section{Materials and Methods}

Production of hybrids between B. kaber, B. juncea, and B. rapa. Auxinic herbicide-R B. kaber and auxinic herbicidesusceptible (S) B. juncea and B. rapa were grown from seed. The seeds were sown in 6 in. plastic pots containing Promix (Plant Products, Mississauga, Canada) and placed in a growth chamber with a 16 -h photoperiod and $22 / 15^{\circ} \mathrm{C}$ day/night temperature. The light intensity and relative humidity were maintained at $350 \mu \mathrm{mol} / \mathrm{m}^{2} / \mathrm{s}$ and $65-75 \%$, respectively. Each pot contained one plant, and the plants were irrigated when required. Plants were fertilized weekly with 20:20:20 (NPK). When plants were flowering, crosses were performed between auxinic herbicide-resistant $B$. kaber and B. juncea or B. rapa following the procedure described by Jugulam et al. (2005). To achieve embryo regeneration and plantlet formation via embryo rescue, immature siliques (narrow, elongated seed capsules) were harvested 3 to $5 \mathrm{~d}$ after pollination. Siliques were disinfected with $70 \%$ ethanol for 1 to $2 \mathrm{~min}$, followed by $20 \%$ commercial bleach (sodium hypochlorite, 5.25\%) containing 3 to 4 drops of Tween 20 per $100 \mathrm{ml}$ for 15 to $20 \mathrm{~min}$, and subsequently rinsed four or five times with sterile deionized water. The siliques were aseptically cultured in a Petri dish (Fig. 1A) containing $15 \mathrm{ml}$ of either of the following two media: A-Murashige and Skoog (1962) salts with Gamborg vitamins (1968), 3\% (w/v) sucrose, and $500 \mathrm{mg} / \mathrm{l}$ casein hydrolysate or B-Murashige and Skoog (1962) salts with Gamborg vitamins (1968), 3\% (w/v) sucrose, $0.5 \mathrm{mg} / 1$ naphthaleneacetic acid (NAA), and $2.5 \mathrm{mg} / 1$ kinetin. The $\mathrm{pH}$ of each medium was adjusted to 5.8 , and $8 \mathrm{~g} / \mathrm{l}$ of agar (Sigma-Aldrich, Oakville, Canada; micropropagation grade, the same agar was used in all other experiments) was added before autoclaving at $121^{\circ} \mathrm{C}$ for $20 \mathrm{~min}$. The siliques were allowed to grow on these media for approximately $2 \mathrm{wk}$. For ovule maturation and regeneration into plantlets, ovules were excised aseptically from the siliques with a forceps and scalpel, and cultured on medium A or B in Petri dishes (two to three ovules per dish; Fig. 1B). All cultures were incubated in a growth room at $24^{\circ} \mathrm{C}$ in light (16-h photoperiod; $50 \mu \mathrm{mol} / \mathrm{m}^{2} / \mathrm{s}$ ) provided by cool white fluorescent lamps (Philips Canada, Toronto, Canada).

Four weeks after ovule culture, hybrid plant regeneration occurred (Fig. 1C), and these young plantlets were subsequently transferred individually to a Magenta box $(300 \mathrm{ml}$ plastic vessels, Magenta Corp., Chicago, IL) containing Murashige and Skoog (1962) salts with Gamborg vitamins (1968) and $1.5 \%(w / v)$ sucrose (medium C). The $\mathrm{pH}$ of medium $\mathrm{C}$ was adjusted to 5.8 , and $8 \mathrm{~g} / 1$ agar was added before autoclaving at $121{ }^{\circ} \mathrm{C}$ for $20 \mathrm{~min}$. After $4 \mathrm{wk}$ on medium $\mathrm{C}$, the hybrids developed roots and shoots. Hybrid plants were clonally multiplied by aseptically culturing nodal segments in Magenta boxes containing medium C. After $6 \mathrm{wk}$ of culture, nodal segments with well-developed roots and shoots were transferred to soil (Promix) and grown under the same conditions as described before for growing B. kaber and B. juncea or B. rapa parental plants.

Assessment of transfer of dicamba resistance and fertility of hybrids. Whole-plant screening was performed to determine the transfer of auxinic herbicide resistance from $B$. kaber into hybrids. Auxinic herbicide-resistant B. kaber, $B$. juncea, and B. rapa, as well as hybrids, were grown in a growth chamber (as described earlier). The seedlings were treated with dicamba [200 g acid equivalent per hectare (ae/ha)] at the three- to four-leaf stage of development using a motorized hood sprayer. Dicamba was used because it is a widely used broadleaf weed herbicide, and $B$. kaber biotypes were found to be highly resistant to dicamba (Heap and Morrison 1992). The sprayer was equipped with a flat-fan nozzle (8002 E) and calibrated to deliver $2001 /$ ha at $276 \mathrm{kPa}$. At 1 and $2 \mathrm{wk}$ after treatment, the seedlings were visually rated for injury. The hybrid plants were classified as $\mathrm{R}$ or $\mathrm{S}$ by comparing the injury response with those of $B$. kaber (dicamba-R) or B. juncea or B. rapa (dicamba-S) seedling response. Susceptibility of plants to dicamba was assessed based on symptoms of epinasty (downward curling of leaf and stem tissue) followed by death; 

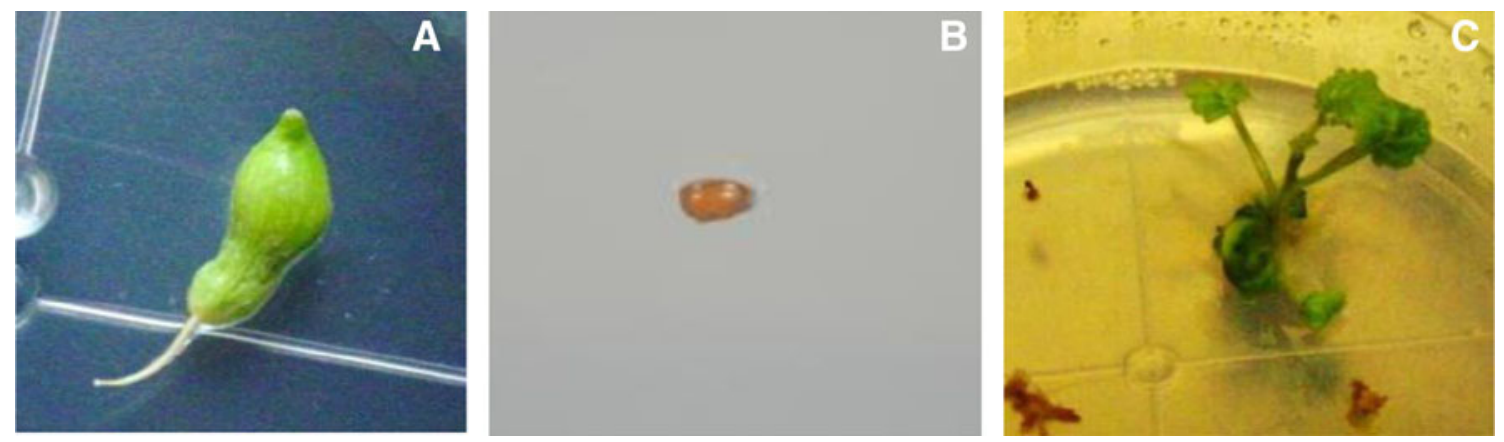

Figure 1. Ovule/embryo rescue procedure to produce hybrids between $B$. juncea, B. rapa, and $B$. kaber. $A$, immature cultured silique; $B$, ovule excised from a silique; and $C$, hybrid plant regenerated from the ovule.

$\mathrm{R}$ plants were not affected by dicamba application. The fertility of the hybrids was tested by performing reciprocal crosses between hybrids and B. juncea or B. rapa.

Repeated backcrosses to introgress dicamba resistance from hybrids into B. juncea or B. rapa. The first generation of backcross progeny $\left(\mathrm{BC}_{1} \mathrm{~F}_{1}\right)$ was produced by performing reciprocal crosses between dicamba-R hybrids and $B$. juncea or $B$. rapa. The hybrids that survived dicamba treatment, as well as $B$. juncea and B. rapa, were grown in a growth chamber (as described previously). Cross-pollinations were performed (Jugulam et al. 2005) between hybrids and $B$. juncea or $B$. rapa to obtain $\mathrm{BC}_{1} \mathrm{~F}_{1}$ seed. Mature seed $\left(\mathrm{BC}_{1} \mathrm{~F}_{1}\right)$ was obtained only from the cross between $B$. juncea $\times$ hybrid. $\mathrm{BC}_{1} \mathrm{~F}_{1}$ seed of $B$. juncea $\times$ hybrid was raised in a growth chamber (as described previously). Because there was poor $\mathrm{BC}_{1} \mathrm{~F}_{1}$ production and germination, only three $\mathrm{BC}_{1} \mathrm{~F}_{1}$ seedlings were grown to maturity. These $\mathrm{BC}_{1} \mathrm{~F}_{1}$ seedlings were not screened for dicamba resistance. When $\mathrm{BC}_{2} \mathrm{~F}_{1}$ seedlings were at the three- to four-leaf stage of development, they were treated with dicamba (200 g ae/ha; as described above).

Assessment of DNA ploidy of hybrids and backcross progeny. The DNA ploidy of hybrids, and backcross progeny, was assessed by flow cytometry according to Kron et al. (2007). Auxinic herbicide-R B. kaber, B. juncea, and B. rapa were used as controls. Based on DNA content obtained by flow cytometry, DNA ploidy of hybrids as well as backcross progeny was estimated.

\section{Results and Discussion}

Production of hybrids between B. juncea or B. rapa and $B$. kaber. Cross-pollination between $B$. juncea or $B$. rapa and dicamba-R $B$. kaber produced siliques but failed to develop in vivo, as they were unable to grow and eventually aborted. Ovule/embryo rescue from immature siliques facilitated hybrid plant production. More hybrids (32) were produced in vitro in crosses between $B$. rapa $\times$ B. kaber compared to $B$. juncea $\times$ B. kaber (six hybrids; Table 1). A similar number of hybrids were produced when embryos were cultured on either medium A or B. The hybrids exhibited several morphological traits of both the parents (leaf shape, stem, and plant height; Fig. 2). The clones of the hybrids were also successfully established in vitro by nodal cuttings.

Dicamba resistance in hybrids and backcross progeny. The results of whole-plant screening demonstrated that 1 hybrid of B. juncea $\times$ B. kaber and 10 hybrids of $B$. rapa $\times$ B. kaber were dicamba-R out of 6 and 32 tested, respectively. After treatment with dicamba, the dicamba-R hybrids exhibited little or no epinasty. This response was similar to dicamba-R

Table 1. Hybrid production between B. juncea, B. rapa, and B. kaber: frequency of embryo regeneration and hybrid plant establishment via in vitro embryo rescue

\begin{tabular}{|c|c|c|c|c|c|}
\hline $\begin{array}{l}\text { Cross } \\
\text { combination }\end{array}$ & $\begin{array}{l}\text { \# of buds } \\
\text { pollinated }\end{array}$ & $\begin{array}{l}\text { \# of siliques } \\
\text { cultured }\end{array}$ & $\begin{array}{l}\# \text { of embryos } \\
\text { excised }\end{array}$ & \# of embryos germinated & $\begin{array}{l}\text { \# of } \\
\text { hybrids } \\
\text { obtained }\end{array}$ \\
\hline B. juncea $\times$ B. kaber & $100-150$ & $80(45$ on $A$ and 35 on $B)$ & $40(22$ on $\mathrm{A}$ and 18 on $\mathrm{B})$ & $\begin{array}{l}6(3 \text { from medium } A \text { and } 3 \text { from } \\
\text { medium B) }\end{array}$ & 6 \\
\hline B. rapa $\times$ B. kaber & $80-100$ & $70(40$ on $A$ and 30 on $B)$ & $50(30$ on $\mathrm{A}$ and 20 on $\mathrm{B})$ & $\begin{array}{l}32(18 \text { from medium } \mathrm{A} \text { and } 14 \text { from } \\
\text { medium } \mathrm{B})\end{array}$ & 32 \\
\hline
\end{tabular}

$A$ MS salts + Gamborg vitamins $+30 \mathrm{~g} / 1$ sucrose $+500 \mathrm{mg} / 1$ casein hydrolysate $(\mathrm{pH} 5.8$ and $8 \mathrm{~g} / \mathrm{l}$ agar), $B$ MS salts + Gamborg vitamins $+30 \mathrm{~g} / 1$ sucrose $+0.5 \mathrm{mg} / \mathrm{l} \mathrm{NAA}+2.5 \mathrm{mg} / \mathrm{l}$ kinetin $(\mathrm{pH} 5.8$ and $8 \mathrm{~g} / \mathrm{l}$ agar $)$ 
Figure 2. Production of hybrids between $B$. juncea, $B$. rapa, and B. kaber. $A-C$ represent $B$. juncea, $B$. rapa, and $B$. kaber, respectively. $D$, $D 1$ and $E, E 1$ illustrate hybrids produced via embryo rescue from crosses between $B$. juncea $\times B$ kaber and B. rapa $\times$ B. kaber, respectively. Note the hybrid exhibiting intermediate characteristics of parents.
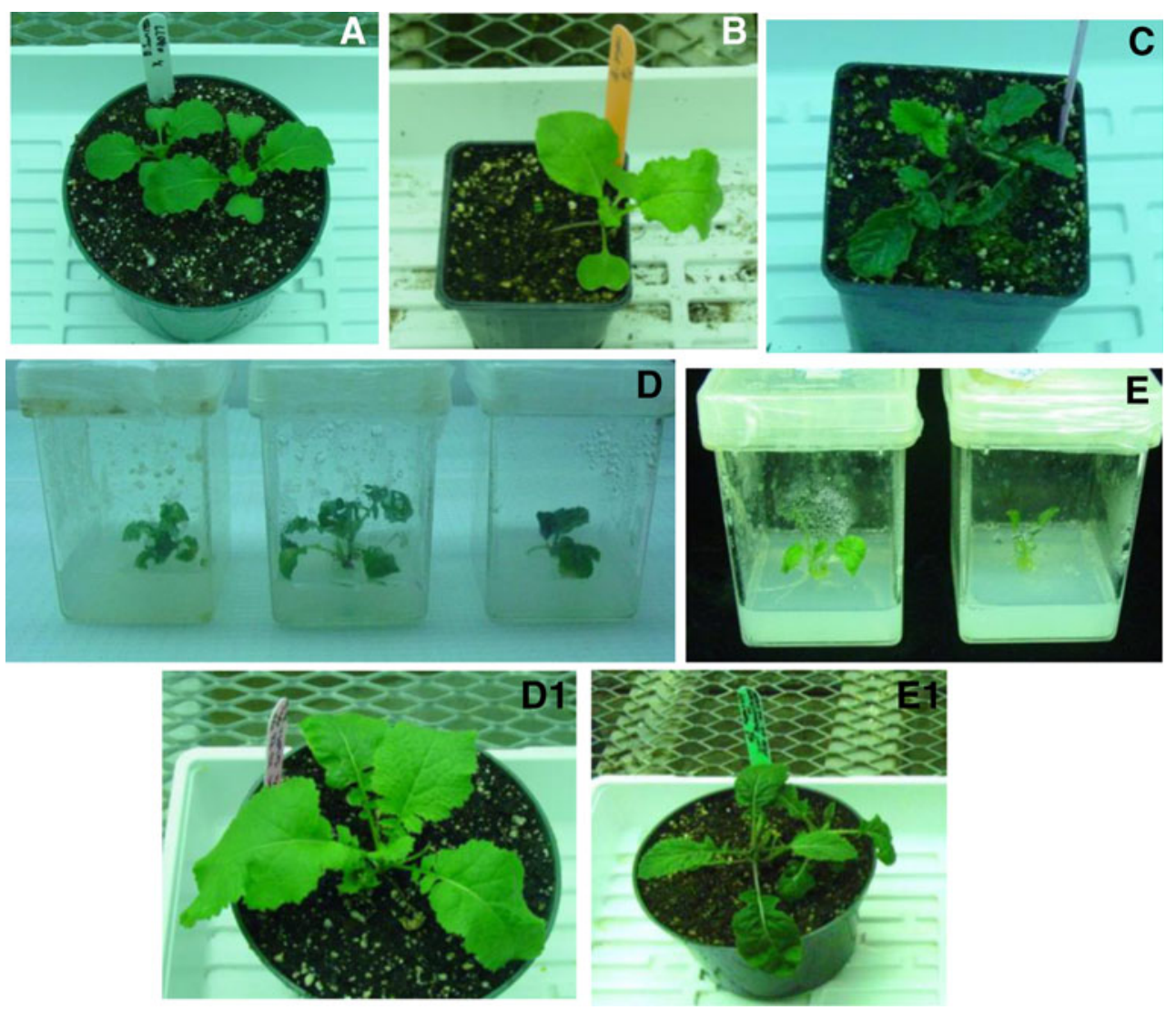

3 wk after dicamba treatment (Fig. 3A, B). The dicamba-R hybrids were maintained in vitro by nodal cuttings.
$B$. kaber plants. These dicamba-R plants matured and flowered (Fig. 3D, E). B. juncea, B. rapa, as well as $\mathrm{S}$ hybrids died
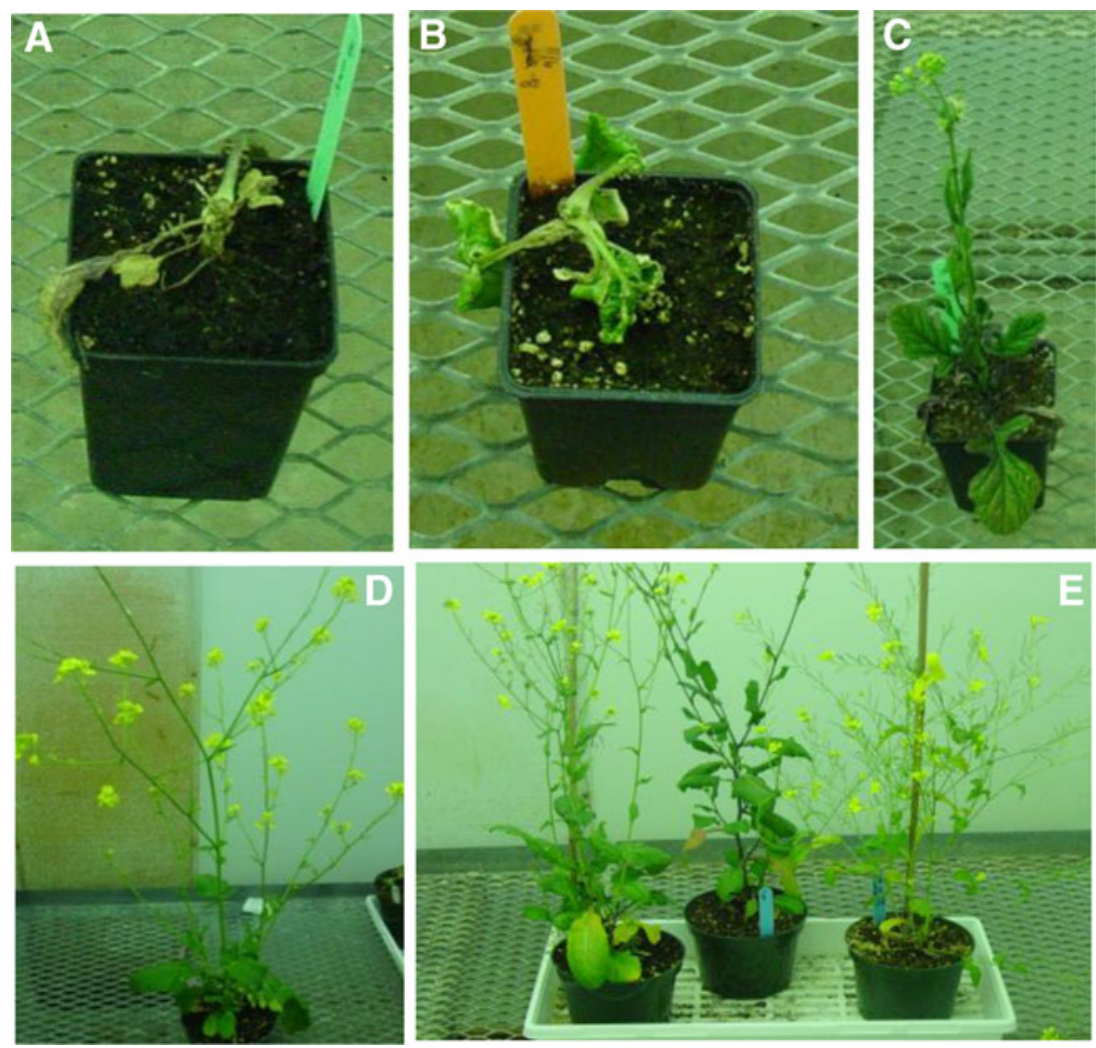

Figure 3. Plant response to dicamba (200 g ae/ha) $5 \mathrm{wk}$ after treatment. $A-C$ represent $B$. juncea, B. rapa, and $B$. kaber, respectively. $D$ and $E$ crossing $B$. juncea $\times$ B. kaber and $B$. rapa $\times$ B. kaber, respectively. 
Reciprocal crosses were performed between parents and dicamba-R hybrids to assess fertility of hybrids as well as generate backcross progeny. For $B$. juncea $\times B$. kaber, crosses were successful only when $B$. juncea was used as the female parent. These results suggest that the one dicamba- $\mathrm{R}$ hybrid recovered from a cross between B. juncea and B. kaber was pollen fertile but female sterile. No other crosses were successful. Approximately $15 \mathrm{BC}_{1} \mathrm{~F}_{1}$ seeds were harvested from crosses between $B$. juncea and the dicamba-R hybrid, and only three seeds germinated. Upon flowering, two of the $\mathrm{BC}_{1} \mathrm{~F}_{1}$ plants were found to be male fertile because the pollen from these plants was able to produce $\mathrm{BC}_{2} \mathrm{~F}_{1}$ seed when used as pollen parent. However, 10 seedlings of $\mathrm{BC}_{2} \mathrm{~F}_{1}$ were established, and when treated with dicamba, the $\mathrm{BC}_{2} \mathrm{~F}_{1}$ progeny showed varying responses. One week after dicamba treatment, six seedlings exhibited severe epinasty and eventually died. The remaining four plants initially showed minor dicamba injury but recovered from the symptoms. Chi-square tests were performed to determine the goodness of fit to a $1: 1(R / S)$ segregation because resistance to dicamba is determined by a single dominant gene in B. kaber (Jasieniuk et al. 1995; Jugulam et al. 2005). The progeny from $\mathrm{BC}_{2} \mathrm{~F}_{1}$ showed 4:6 $(R / S)$ segregation with a $\chi^{2}$ value of 0.4 (which is less than the table value of " 3.841 " at 0.05 probability for $1 \mathrm{df}$ ). The 1:1 segregation of $R / S$ in backcross 2 suggests that the gene controlling dicamba resistance may have been transferred to $B$. juncea. However, further efforts are required to produce advanced generations of backcrosses and determine the segregation ratios of dicamba- $\mathrm{R}$ or dicamba-S in these progeny to ascertain stable introgression of dicamba resistance trait from $B$. kaber into $B$. juncea.

In the case of B. rapa $\times$ B. kaber hybrids, 5 out of 10 dicamba-R hybrids also produced pollen. However, no seed was obtained when this pollen was used in backcrosses with B. rapa; these hybrids were also female sterile. Therefore, introgression of dicamba resistance into B. rapa was not successful. Future experiments will determine the possibility of transfer of dicamba resistance into B. rapa.

Assessment of DNA ploidy of hybrids and backcross progeny. Flow cytometry was used to quantify the amount of DNA in hybrid as well as parental plants and to estimate ploidy level. Only one hybrid derived from $B$. juncea $\times B$. kaber was a DNA triploid (estimated DNA ploidy of 2.96; Table 2), whereas the five other hybrids were tetraploids (Table 2). These results suggest that the five putative hybrids that were DNA tetraploids (Table 2) may have been derived in vitro from somatic tissue rather than the fertile embryo. Moreover, all these hybrids were found to be dicamba-S. The flow cytometry results of $\mathrm{BC}_{1} \mathrm{~F}_{1}$ and
$\mathrm{BC}_{2} \mathrm{~F}_{1}$ progeny of $B$. juncea indicated that these plants were either DNA tetraploids $(4 \times$, possibly somatic) or aneuploids (plants possessing abnormal number of chromosomes, that is, an extra or missing chromosome, such as $4.2 \times, 4.3 \times$, $4.4 \times, 4.6 \times$, or $4.7 \times$; Table 2). Even though DNA was quantified by flow cytometry in $B$. rapa $\times B$. kaber hybrids (Table 2), the hybridity of plants was ascertained by plant morphology as well as their resistance response to dicamba treatment (Fig. 3E).

Interspecific crosses for transferring agronomically important traits are routinely performed among agricultural crops. However, interspecific gene transfer is often difficult, specifically among species having different genome or chromosome numbers because of potential irregularities during meiosis. The family Brassicaceae consists of diploids (B. rapa, $B$. oleraceae, Brassica nigra, and B. kaber) as well as allotetraploids (B. juncea, B. napus, and B. carinata). The

Table 2. DNA ploidy of parents, hybrids, and backcross progeny

\begin{tabular}{|c|c|c|}
\hline Plants tested & $\begin{array}{l}\text { DNA content (pg) } \\
\text { determined by } \\
\text { flow cytometry }\end{array}$ & $\begin{array}{l}\text { Estimated } \\
\text { DNA ploidy }\end{array}$ \\
\hline \multicolumn{3}{|l|}{ Parents: } \\
\hline B. juncea & 2.24 & 3.95 \\
\hline B. rapa & 1.08 & 1.93 \\
\hline B. kaber & 1.10 & 1.98 \\
\hline \multicolumn{3}{|l|}{ Hybrids: } \\
\hline B. juncea $\times$ B. kaber \#1 & 1.60 & 2.96 \\
\hline B. juncea $\times$ B. kaber \#2 & 2.21 & 4.06 \\
\hline B. juncea $\times$ B. kaber \#3 & 2.18 & 3.86 \\
\hline B. juncea $\times$ B. kaber \#4 & 2.17 & 3.84 \\
\hline B. juncea $\times$ B. kaber $\# 5$ & 2.17 & 3.84 \\
\hline B. juncea $\times$ B. kaber $\# 6$ & 1.18 & 3.86 \\
\hline \multicolumn{3}{|l|}{ Hybrids: } \\
\hline B. rapa $\times$ B. kaber $\# 1$ to $\# 32$ & 1.04 to 1.12 & 1.83 to 1.97 \\
\hline \multicolumn{3}{|l|}{ Backcrosses with $B$. juncea } \\
\hline \multicolumn{3}{|l|}{ Backcross 1: } \\
\hline $\mathrm{BC}_{1} \mathrm{~F}_{1} \# 1$ & 2.61 & 4.62 \\
\hline $\mathrm{BC}_{1} \mathrm{~F}_{1} \# 2$ & 2.66 & 4.70 \\
\hline $\mathrm{BC}_{1} \mathrm{~F}_{1} \# 3$ & 2.58 & 4.56 \\
\hline \multicolumn{3}{|l|}{ Backcross 2: } \\
\hline $\mathrm{BC}_{2} \mathrm{~F}_{1} \# 1$ & 2.45 & 4.32 \\
\hline $\mathrm{BC}_{2} \mathrm{~F}_{1} \# 2$ & 2.45 & 4.33 \\
\hline $\mathrm{BC}_{2} \mathrm{~F}_{1} \# 3$ & 2.47 & 4.37 \\
\hline $\mathrm{BC}_{2} \mathrm{~F}_{1} \# 4$ & 2.41 & 4.25 \\
\hline $\mathrm{BC}_{2} \mathrm{~F}_{1} \# 5$ & 2.30 & 4.06 \\
\hline $\mathrm{BC}_{2} \mathrm{~F}_{1} \# 6$ & 2.33 & 4.11 \\
\hline $\mathrm{BC}_{2} \mathrm{~F}_{1} \# 7$ & 2.44 & 4.31 \\
\hline $\mathrm{BC}_{2} \mathrm{~F}_{1} \# 8$ & 2.27 & 4.01 \\
\hline $\mathrm{BC}_{2} \mathrm{~F}_{1} \# 9$ & 2.31 & 4.08 \\
\hline $\mathrm{BC}_{2} \mathrm{~F}_{1} \# 10$ & 2.42 & 4.27 \\
\hline
\end{tabular}


allotetraploids of Brassica species are naturally evolved and possess two of the three genomes; that is, $\mathrm{AA}, \mathrm{BB}$, or $\mathrm{CC}$. Natural crossing among the Brassica species was reported to occur with varying difficulty (Myers 2006). However, the majority of hybrid production from crosses between a diploid and tetraploid Brassica species has been successful when in vitro techniques such as embryo rescue or protoplast fusions were employed (Bing et al. 1995; Momotaz et al. 1998; Hu et al. 2002). In this study, we report for the first time the successful production of hybrids and transfer of auxinic herbicide resistance from $B$. kaber to $B$. juncea $\times$ B. kaber hybrids. In vitro culture of immature siliques 3-5 d after pollination for 2 wk, followed by excision of embryos/ovules yielded higher number of hybrids in crosses between B. rapa $\times$ B. kaber compared to B. juncea $\times$ B. kaber (Table 1 ). Nonetheless, production of backcross progeny was successful only with B. juncea.

B. juncea is an allotetraploid with an AABB genome, whereas $B$. rapa is a diploid with an AA genome alone. Wild mustard is a diploid, possessing SarSar genome (Snowdon et al. 2000). The SarSar genome of B. kaber is closely related to Brassica species that contain B genome (Warwick and Black 1991). Additionally, based on cytogenetic analyses by Mizushima (1980), it appears that three bivalents can be formed between B. kaber (SarSar genome) and B. rapa chromosomes. Furthermore, $B$. kaber has potential to form up to seven bivalents with chromosomes of BB genome (Mizushima 1980). These cytological studies suggest that there is high possibility of obtaining successful interspecific hybrids between $B$. kaber and B. juncea. Nevertheless, in this present study, we obtained higher number of interspecific hybrids between $B$. rapa and B. kaber (up to 32 hybrids) than with $B$. juncea (six hybrids; Table 1). This may be due to the increased response of $B$. rapa and $B$. kaber embryos to in vitro culture manipulations. Finally, the results from this research offer potential for production of auxinic herbicide-R oil seed Brassica crops, specifically, B. juncea and B. rapa.

Acknowledgments The financial support to JCH from the Natural Science and Engineering Research Council of Canada and BASF, NC, USA through NSERC-CRD grant is gratefully acknowledged.

Open Access This article is distributed under the terms of the Creative Commons Attribution License which permits any use, distribution, and reproduction in any medium, provided the original author(s) and the source are credited.

\section{References}

Bing DJ, Downey RK, Rakow FW (1995) An evaluation of the potential intergeneric gene transfer between Brassica napus and Sinapis arvensis. Plant Breed 114:481-484
Buchanan FS, Swanton CJ, Gillespie TJ (2009) Wild mustard. Available via FACTSHEET. http://www.omafra.gov.on.ca/english/ crops/facts/03-043.htm\#c2. Accessed 5 August 2012

Gamborg OL, Miller RA, Ojima K (1968) Nutrient requirements of suspension cultures of soybean root cells. Exp Cell Res 50:151158

Hall JC, Webb SR, Deshpande S (1996) An overview of auxinic herbicide resistance: wild mustard as a case study. In: Brown TM (ed) Molecular genetics and evolution of pesticide resistance. American Chemical Society, Washington, pp 28-43

Heap IM and Morrison IN (1992) Resistance to auxin-type herbicides in wild mustard (Sinapis arvensis L) populations in western Canada. Annual Meeting of Weed Science Society of America, Abstract \# 32, p. 164

Hu Q, Anderson SB, Dixelius C, Hansen LN (2002) Production of fertile intergeneric somatic hybrids between Brassica napus and Sinapis arvensis for the enrichment of the rapeseed gene pool. Plant Cell Rep 21:147-152

Inomata N (1988) Intergeneric hybridization between Brassica napus and Sinapis arvensis and their crossability. Eucarpia Cruciferae Newsl 1:22-23

Jasieniuk M, Morrison IN, Brule-Babel AL (1995) Inheritance of dicamba resistance in wild mustard (Brassica kaber). Weed Sci 43:192-195

Jugulam M, McLean MD, Hall JC (2005) Inheritance of picloram and 2,4-D resistance in wild mustard (Brassica kaber). Weed Sci 53:417-423

Kron P, Suda J, Husband BC (2007) Application of flow cytometry to evolutionary and population biology. Annu Rev Ecol Evol Syst 38:847-876

Mathias P (1991) Improved embryo rescue technique for intergeneric hybridization between Sinapis species and Brassica napus. Cruciferae Newsl 14(15):90-91

Mithila J, Hall JC (2007) Production of an auxinic herbicide-resistant microspore-derived haploid wild mustard (Sinapis arvensis L.) plant. Crop Prot 27:357-362

Mithila J, McLean MD, Chen S, Hall JC (2012) Development of nearisogenic lines and identification of markers linked to auxinic herbicide resistance in wild mustard (Sinapis arvensis). Pest Manag Sci 68:548-556

Murashige T, Skoog F (1962) A revised medium for rapid growth and bioassays with tobacco tissue culture. Physiol Plant $15: 473-497$

Mizushima U (1950) Karyogenetic studies of species and genus hybrids in the tribe Brassiceae of Cruciferae. Tohoku J Agric Res $1: 1-14$

Mizushima U (1980) Genome analysis in Brassica and allied genera. In: Tsunoda T, Hinata K, Gomez-Campo G (eds) Brassica crops and wild allies, Biology and breeding. Scientific Societies Press, Tokyo, pp 89-106

Momotaz A, Kato M, Kakihara F (1998) Production of intergeneric hybrids between Brassica and Sinapis species by means of embryo rescue techniques. Euphytica 103:123-130

Myers JR (2006) Outcrossing potential for Brassica species and implications for vegetable crucifer seed crops of growing oilseed brassicas in the Willamette Valley. Extension publication, Oregon State University

Penuik MG, Romano ML, Hall JC (1993) Physiological investigations into the resistance of wild mustard (Sinapis arvensis L) biotype to auxinic herbicide. Weed Res 33:431-440

Prakash S, Hinata K (1980) Taxonomy, cytogenetics and origin of crop brassicas, a review. Oper Bot 55:3-57

Snowdon RJ, Winter H, Diestel A (2000) Development and characterization of Brassica napus-Sinapis arvensis addition lines exhibiting resistance to Leptosphaeria maculans. Theor Appl Genet 101:1008-1014 
Tonguc M, Griffiths PD (2004) Transfer of powdery mildew resistance from Brassica carinata to Brassica oleracea through embryo rescue. Plant Breed 123:587-589

Warwick SI, Black LD (1991) Molecular systematics of Brassica and allied genera (subtribe Brassicinae, Brassiceae) - chloroplast genome and cytodeme congruence. Theor Appl Genet 82:81-92
Webb SR, Hall JC (1995) Auxinic herbicide-resistant and susceptible wild mustard (Sinapis arvensis L.) biotypes: effect of auxinic herbicides on seedling growth and auxin-binding activity. Pestic Biochem Physiol 52:137-148

Zheng HG, Hall JC (2001) Understanding auxinic herbicide resistance in Sinapis arvensis L.: physiological, biochemical and molecular genetic approaches. Weed Sci 49:276-281 